PREPARED FOR THE U.S. DEPARTMENT OF ENERGY, UNDER CONTRACT DE-AC02-76CH03073

PPPL-3655

PPPL-3655

UC-70

Boronization on NSTX using Deuterated Trimethylboron

by

W.R. Blanchard, R.C. Gernhardt, H.W. Kugel, and P.H. LaMarche

January 2002

NM|

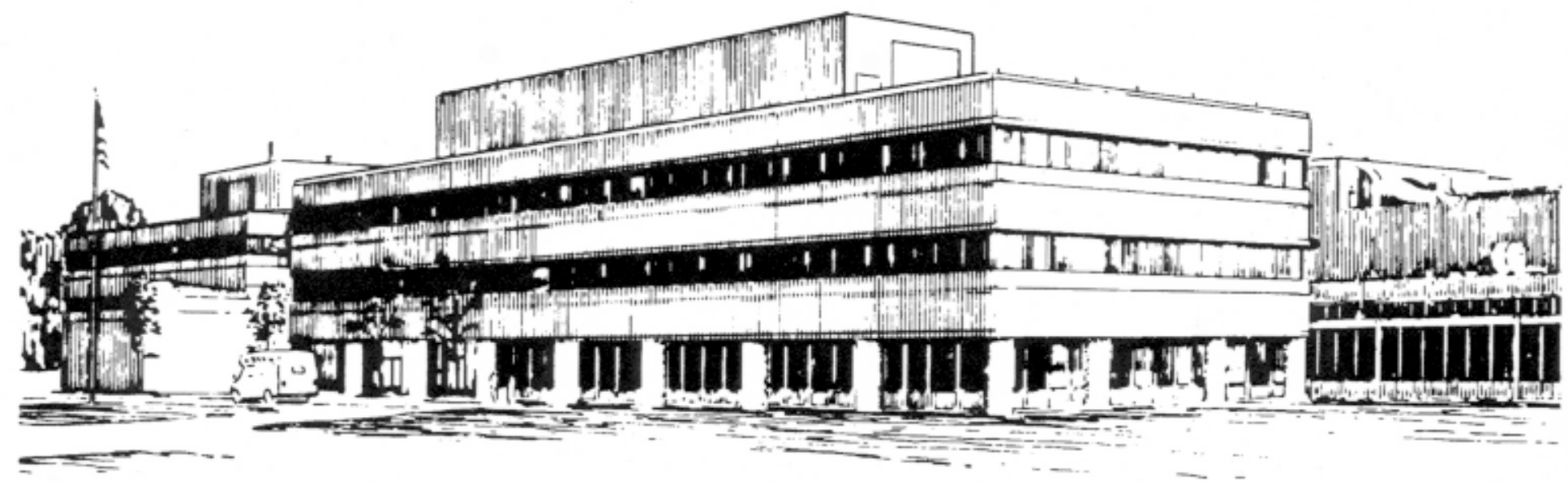

PRINCETON PLASMA PHYSICS LABORATORY PRINCETON UNIVERSITY, PRINCETON, NEW JERSEY 


\section{PPPL Reports Disclaimer}

This report was prepared as an account of work sponsored by an agency of the United States Government. Neither the United States Government nor any agency thereof, nor any of their employees, makes any warranty, express or implied, or assumes any legal liability or responsibility for the accuracy, completeness, or usefulness of any information, apparatus, product, or process disclosed, or represents that its use would not infringe privately owned rights. Reference herein to any specific commercial product, process, or service by trade name, trademark, manufacturer, or otherwise, does not necessarily constitute or imply its endorsement, recommendation, or favoring by the United States Government or any agency thereof. The views and opinions of authors expressed herein do not necessarily state or reflect those of the United States Government or any agency thereof.

\section{Availability}

This report is posted on the U.S. Department of Energy's Princeton Plasma Physics Laboratory Publications and Reports web site in Fiscal Year 2002. The home page for PPPL Reports and Publications is: http://www.pppl.gov/pub_report/

DOE and DOE Contractors can obtain copies of this report from:

U.S. Department of Energy

Office of Scientific and Technical Information

DOE Technical Information Services (DTIS)

P.O. Box 62

Oak Ridge, TN 37831

Telephone: (865) 576-8401

Fax: (865) 576-5728

Email: reports@adonis.osti.gov

This report is available to the general public from:

National Technical Information Service

U.S. Department of Commerce

5285 Port Royal Road

Springfield, VA 22161

Telephone: 1-800-553-6847 or

(703) 605-6000

Fax: (703) 321-8547

Internet: http://www.ntis.gov/ordering.htm 


\title{
Boronization on NSTX using Deuterated Trimethylboron *
}

\author{
W. R. Blanchard, R. C. Gernhardt, H. W. Kugel, P. H. LaMarche \\ Princeton Plasma Physics Laboratory, Princeton, NJ 08543, USA
}

\begin{abstract}
Boronization on the National Spherical Torus Experiment (NSTX) has proved to be quite beneficial with increases in confinement and density and decreases in impurities observed in the plasma. The boron has been applied to the interior surfaces of NSTX, about every 2 to 3 weeks of plasma operation, by producing a glow discharge in the vacuum vessel using deuterated trimethylboron (TMB) in a $10 \%$ mixture with helium. Special NSTX requirements restricted the selection of the candidate boronization method to the use of deuterated boron compounds. Deuterated TMB met these requirements but is a hazardous gas and special care in the execution of the boronization process is required. This paper describes the existing GDC, Gas Injection, and Torus Vacuum Pumping System hardware used for this process, the glow discharge process, and the automated control system that allows for remote operation to maximize both the safety and efficacy of applying the boron coating. The administrative requirements and the detailed procedure for the setup, operation and shutdown of the process are also described.
\end{abstract}

\section{INTRODUCTION}

$\mathrm{T}$ HE control of impurity gases and recycling of the fuel gas is of critical importance to the operation of a fusion device. Impurity gases and recycling affect the density, confinement time and effective charge $\left(Z_{\text {eff }}\right)$ of plasmas. A number of wall conditioning techniques and materials have been utilized over the years to control impurities including coating the interior of vacuum vessels with boron compounds[1]. One of these compounds, deuterated diborane $\left(\mathrm{B}_{2} \mathrm{D}_{6}\right)$, was used to condition the interior of TFTR [2,3] and had a beneficial effect on the performance of the machine. The difficulty with diborane is that it is an extremely hazardous gas and significant measures were taken to mitigate its toxic and flammable properties. Trimethylboron (TMB) $\left[\mathrm{B}\left(\mathrm{CD}_{3}\right)_{3}\right]$ is a much less hazardous gas than diborane and it was used successfully on other machines [1,4]. Therefore TMB appeared to be a good candidate for conditioning the interior of NSTX (National Spherical Torus Experiment) using a glow discharge cleaning (GDC) procedure. It was decided to limit the on-site quantity of TMB to 50 grams or less using bottles of helium (90\%) and TMB (10\%) mixtures. A versatile PLC controlled gas injection system with automated controls and interlocks had already been in use for GDC on NSTX and was easily modified for TMB use. A comprehensive review of TMB use at PPPL was undertaken.
A thorough training effort of TMB operators was completed and a detailed procedure was written and reviewed prior to the initial application of TMB. TMB boronization using He/TMB GDC was performed 9 times over the last two NSTX operating sessions between September 2000 and July 2001. This resulted in significant improvements in plasma performance [5].

This process deposited boron films over the entire interior of the vessel, but the subsequent erosion of this deposition during plasma operations is believed to take place predominantly on plasma wetted surfaces. Plasma fueling with TMB had been tested previously on TEXTOR [6] and TdeV [7] and found to transport boron in the edge plasma to plasma wetted surfaces. Late in the most recently completed operational period, a test was performed of fueling with a $90 \%$ helium and 10\% TMB mixture. It was found that after 12 discharges, the central radiated power decreased by a factor of 2 during both ohmic and NBI fiducial discharges. Both of these methods of applying boron to the interior of NSTX have produced beneficial effects on plasma performance $[5,8]$.

\section{Motivation}

The injection of TMB into a glow discharge in NSTX was intended to provide a hard coating of boron to enhance the operational capabilities and performance of NSTX. During the glow discharge process, the TMB is broken down into highly reactive radicals. These radicals adhere to the walls of the vessel and react to form a protective film. This film is also highly hygroscopic and greatly enhances the pumping of water and other active impurity gases thereby improving the performance of the machine. The interior of the TFTR tokamak at PPPL had been conditioned with boron using deuterated diborane $\left(\mathrm{B}_{2} \mathrm{D}_{6}\right)$ as the working gas in a glow discharge cleaning technique. This procedure proved to have significant beneficial effects but the difficulty with it was that diborane is extremely hazardous. TMB was previously used on machines such as TEXTOR and COMPASS with results similar to that of diborane $[1,4]$, and improved plasma performance by lowering $\mathrm{z}_{\mathrm{eff}}$, resistivity and radiated power. In addition, the recent commercial availability of deuterated TMB was an important consideration. In NSTX RF experiments, the presence of hydrogen can cause parasitic resonance effects. In order to minimize the hydrogen inventory in the vacuum vessel, hydrogenic boron compounds cannot be used for boronization. Therefore, deuterated TMB appeared to be a suitable candidate for boronization and an effort was initiated to apply it to NSTX. 


\section{SAFETY CONCERNS}

TMB is a toxic and pyrophoric gas. The regulatory Threshold Limit Value (TLV) for TMB is 7 PPM. The TLV is the limit where a person can work for 8 continuous hours with no effect. TMB releases approximately $3100 \mathrm{~kJ} / \mathrm{mole}$ of energy when burned. TMB has a molecular weight of 64 and is much heavier than air and it also has a strong choking odor. The gas mixture used for the application of the TMB is $90 \%$ helium and 10\% TMB. The maximum inventory allowed in the NSTX Test Cell at any one time is limited to 50 grams which releases approximately $2400 \mathrm{~kJ}$ when burned.

The use of TMB at the PPPL was extensively reviewed by members of the physics and engineering staff and representatives of the safety division at the laboratory. A number of engineering modifications and administrative requirements were employed to ensure the safety of the process. The exhausts for all of the vacuum pumps on NSTX were connected to the existing stainless steel exhaust manifold that is distributed throughout the NSTX Test Cell. This manifold is connected to the site stack system that exhausts gases to the outside. The existing burst disks on the gas delivery system were also connected to the exhaust manifold. The stainless steel bottles of helium/TMB were three liters in volume and limited to approximately 200 psig. Therefore if the bottle was completely exhausted into the delivery line, the gas could not breach any part of the containment system and be released into the test cell. No more than ten grams of TMB (one bottle) was installed in the test cell for use at any one time. A nitrogen line was connected into the exhaust manifold to purge the manifold of air during the TMB process and thereby precluded an explosive mixture in the exhaust line. An additional pressure gauge was added to the gas delivery system and was positioned adjacent to the TMB bottle valve to ensure against the unlikely situation where not all of the appropriate valves were opened during the pump/purge routine. This pressure gauge was also interlocked to stop the process at a designated value (30 psia) at the conclusion of the TMB GDC process. It was important to maintain the TMB bottle at a positive pressure relative to atmospheric pressure in order to preclude air leaking into the bottle and producing an explosive mixture.

A comprehensive Failure Modes and Effects Analysis was developed to examine possible accident scenarios and their mitigation. A complete helium leak check was done of the gas delivery system to ensure its integrity and a pre-operational test procedure was performed for testing the system thoroughly prior to using TMB. A number of NSTX machine technicians were given training on the hazards of TMB, the Material Safety Data Sheet (MSDS), the use of the gas leak detection unit, the hardware configuration and the procedure for the setup, application and removal of the TMB. Additionally, Emergency Service Unit (ESU) personnel were also trained in the hazards of TMB and the response to a leak or fire.

\section{HARDWARE CONFIGURATION}

The NSTX vacuum vessel is made up of a 5/8" thick 316 stainless steel outer shell with a volume of 28,700 liters with approximately $41 \mathrm{~m}^{2}$ of plasma facing surfaces [9]. NSTX is a low aspect ratio machine that is somewhat spherical in shape with a small diameter inner core center stack. The plasma facing wall in the interior of the vacuum vessel consists of graphite tiles. These tiles cover the center stack, upper and lower passive plates near the midplane of the torus and divertor plates at the top and bottom of the vacuum vessel (Fig 1). The pumping system consists of two turbomolecular pumps (TMPs) backed by a roots blower pump and mechanical pump package and the exhaust of the pumping system is hard plumbed to the outside vent of the test cell. The vacuum pumping system has an effective nitrogen pumping speed of approximately 2200 liters/sec. There is a nitrogen gas manifold that runs throughout the test cell and, as part of the modification of the existing equipment, this nitrogen line was tied into the vacuum system's exhaust line to purge the exhaust line of air during the TMB operation.

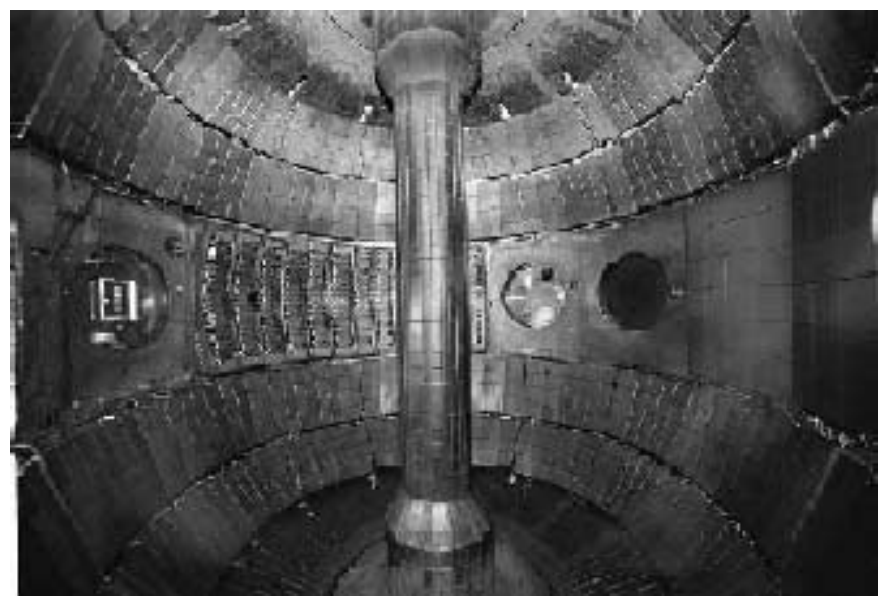

Fig. 1. The interior of the NSTX vacuum vessel. The vacuum vessel volume is 28,700 liters with approximately $41 \mathrm{~m}^{2}$ of plasma facing graphite surfaces and a narrow center stack that houses PF and TF coils.

NSTX has twelve bays (A-L) evenly distributed toroidally around the vacuum vessel. The GDC system consists of two fixed electrodes located at the mid-plane of the vacuum vessel located at Bays $\mathrm{G}$ and $\mathrm{K}$. Each of these glow probes is connected to a 1000 volt power supply. Two filaments were installed inside the vacuum vessel and biased to 500 volts to produce emission electrons that aid in the breakdown of the glow discharge at pressures lower than would otherwise be possible. Typically on NSTX, helium GDC is initiated and operated at 4 mTorr. This is also the operating pressure for the TMB GDC.

The Gas Injection System consists of four gas injection assemblies. One is located at a port on the top of the machine, one at the lower dome of the vacuum vessel near the center stack, one at the midplane and one at the torus end of the vacuum system pump duct on which the TMPs are housed. The injector located at the front of the pump duct at Bay L was dedicated to TMB injection (Fig 2). Except for the lower dome gas injector that was designed for a particular experimental application, the gas injection assemblies are similar in design. They consist of a piezo electric pulse valve and a plenum that can be isolated from the gas delivery system. Each system also contains a gas delivery line with two regulators and a pumpout capability for the entire 


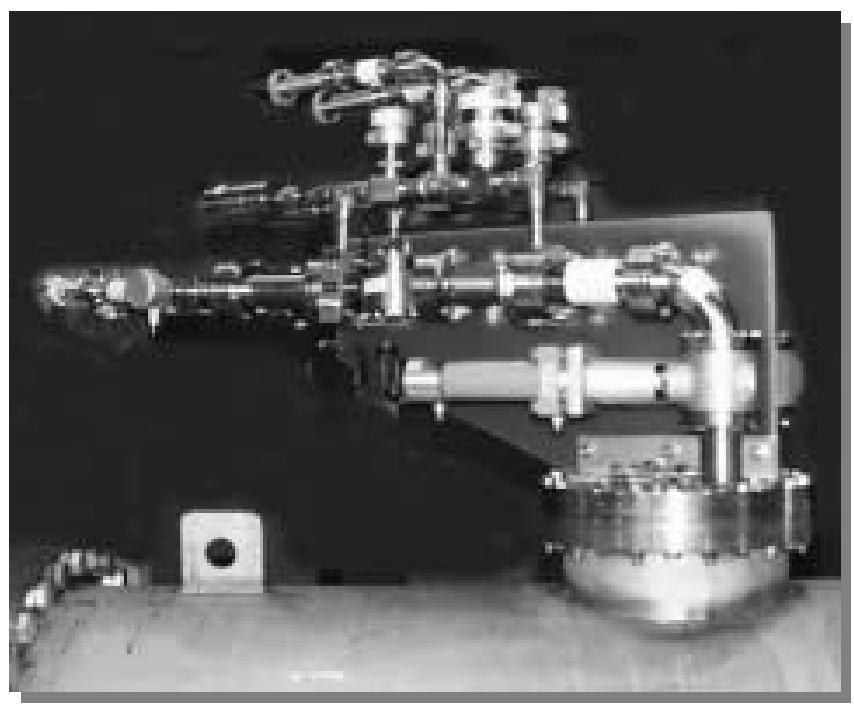

Fig. 2. The Bay L injector used for TMB injection during initial installation on the pumpduct. The gas injection assembly consists mainly of a piezoelectric pulse valve, interface valve, gas delivery line and pumpout line.

delivery system. One of the regulators is for precisely setting the delivery pressure and has a maximum output pressure of 20 psig. The residual gas analyzer (RGA) is a quadruple mass spectrometer. The RGA is configured with its own pumping system and a $50 \mathrm{~mm}$ orifice can be introduced between the vacuum vessel and the RGA for pressure reduction during GDC.

\section{SETUP AND OPERATION}

A detailed procedure was written to ensure that the setup for TMB operation is done safely and consistently. The boron team consists of two of the trained technicians and a cognizant engineer. The cognizant physicist is also present to direct any variations in the application technique and for data acquisition. Prior to setting up the for TMB injection, a pre-job brief is conducted by the cognizant engineer to review the safety aspects of the procedure. Fire retardant clothes, safety glasses, face shield and gloves are worn by the two technician team members when handling the TMB during the hookup of the bottle (Fig. 3). ESU is notified of the operation and the test cell is put into purge mode by HVAC personnel to maximize the exchange of air. All personnel are excluded from the test cell except for team members during the TMB hookup portion of the procedure and only one bottle (10 grams) is used at a time. The TMB is kept outside in a dedicated locked and caged area. The dedicated gas delivery system at Bay L has a second separate connection for a bottle of helium which is used to pump/purge the delivery lines prior to backfilling with TMB. A completely separate gas delivery and injection system (Bay K top) is configured with helium to initiate the glow discharge and for co-injection during the application of the TMB. A portable camera is set up to allow monitoring of the TMB bottle regulator pressure from the NSTX control room to ensure the bottle is not depleted below 30 psia in addition to the previously mentioned pressure gauge interlock.
All of the valves are inspected to ensure their correct position and the nitrogen purge of the exhaust manifold is started. The TMB bottle is then placed in its holder in the test cell and connected to the gas delivery system. During the removal of the plug on the TMB bottle, one technician removes the plug and connects the bottle to the flex line while a second team member uses the gas leak detector to measure for any leaks. The bottle is held in a horizontal position with the plug directed down so that if there is a leak the TMB will be directed down toward the floor. The entire system up to the TMB bottle is then pumped and purged with helium five times using the auxiliary bottle of helium. The system is then left pressurized with helium and a pressure drop leak test is performed. The helium is then pumped out and the TMB bottle valve is opened and the gas delivery system is then backfilled with TMB. The TMB and the separate Bay K helium gas injection system are then backfilled to approximately the same line pressure so that each injector delivers approximately the same amount of gas during the GDC process.

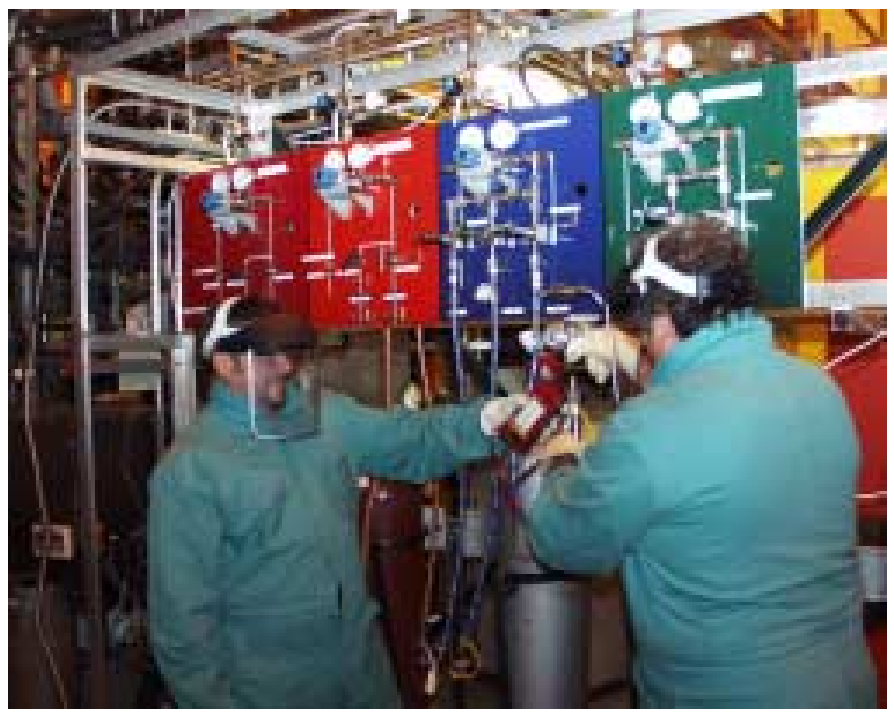

Fig. 3. Two TMB team members outfitted in the protective gear and with the gas sniffer for detecting any TMB during the process.

Once the setup of the TMB in the test cell is complete, the TMB team retires to the NSTX control room where the TMB GDC is operated remotely. One of the two TMPs is then isolated from the vacuum vessel. The gas delivery system, gas injection assembly and glow discharge cleaning system are operated completely by a PLC based control system. The system is completely automated for GDC (Fig 4). Once the appropriate injector(s) have been chosen, it ensures the neutral beam valve is shut, closes the appropriate diagnostic shutters and torus interface valves, configures the residual gas analyzer, applies voltage to the pulse valves and controls the pressure to a pre-set value (4 mTorr). Additionally the automated PLC controls the filaments used for the breakdown of the GDC and it applies the voltage to the GDC probes. During GDC the probes are maintained at approximately $450 \mathrm{~V}$ and each probe draws approximately $1.5 \mathrm{amps}$. The glow is initiated with the second independent helium injector for approximately 5 minutes and then the TMB injection is started. However, prior 
to the start of TMB injection, the filaments are turned off and allowed to cool so as to minimize the formation of tungsten borides, which might embrittle the filaments. In this configuration the GDC consists of approximately 5\% TMB and $95 \%$ helium.

The entire NSTX gas injection system is protected against improperly configured operation via the interlocking control program for the PLC. Loss of AC power or PLC failure results in field devices defaulting to a safe condition. Gas supply valves and interface valves close and the drive voltage for the pulse valve is removed as is the voltage for the GDC probes. All four gas injector systems are disarmed and disabled. A watchdog timer ensures that AC power is removed until normal conditions are restored for operation. The gas feed is also interlocked to shutdown automatically on the loss of the GDC current.

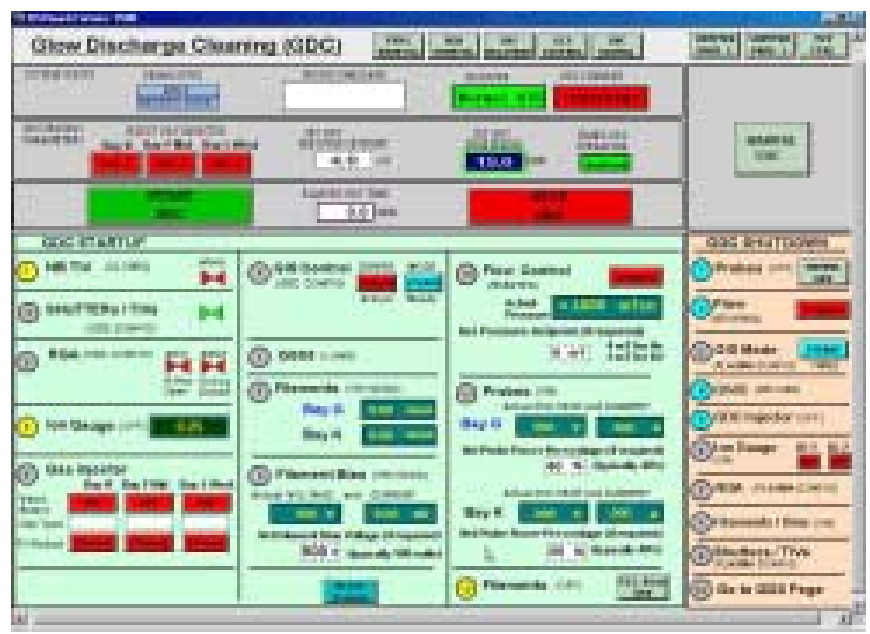

Fig. 4. The PLC page for the automated GDC process on NSTX where the operator can monitor the TMB/GDC process for correct operation.

The TMB application takes about 160 minutes using one TMP and two injectors for fueling the GDC. When the TMB bottle pressure reaches $30 \mathrm{psia}$, the PLC is programmed to automatically shut down GDC and the gas injection. With the TMB bottle isolated, another glow discharge is initiated using the residual gas in the delivery lines in order to deplete the lines of TMB. GDC is then shutdown from the control room. The process of removing the TMB is similar to its installation in the test cell with five pump/purges of the lines with helium prior to disconnecting the TMB flex line from the bottle. Once the TMB bottle is removed from the NSTX test cell, the area is cleared of personnel, the test cell is locked up and two hours of helium-only GDC is performed from the control room once again. This helium-only GDC is performed in order to deplete the first walls of excess deuterium that was adsorbed during the TMB process. At the completion of the helium glow discharge, all systems are returned to their normal configuration.

\section{RESULTS}

The process described above for applying TMB to the interior of the vacuum vessel has proven to be a safe and effective means of coating the first walls of NSTX. TMB has been applied to the interior of NSTX nine times using the glow discharge technique since September 2000 and once using the TMB mixture as a fueling gas in NSTX plasmas. A $25 \mathrm{~mm}$ square silicon sample was placed on the vacuum vessel wall at Bay $\mathrm{E}$ and analyzed after the initial boronization for thickness and composition. The thickness of the boron on the sample was $100 \mathrm{~nm}$, which was in good agreement with the calculated deposition thickness expected assuming uniform deposition [5]. The B/C stochiometry was $1 / 3$, in good agreement with the ratio of the TMB molecule. The $(\mathrm{C}+\mathrm{B}) / \mathrm{D}$ ratio was $2 / 3$ which is consistent with the two hours of helium GDC performed immediately after TMB to deplete the walls of deuterium.

The RGA data showed significant reduction in the water (mass 18) and CO (mass 28) peaks after the completion of boronization. Plasma performance also improved after the application of TMB with reductions in radiated power (factor of two), $\mathrm{Z}_{\mathrm{eff}}$ (factor of three), oxygen (factor of 15) and copper to less than the detection limit [5].

\section{ACKNOWLEDGMENT}

We thank Dr. S. Fielding of the MAST Project at the Culham Science Center for useful technical contributions to this effort. We also thank T. Provost, J. Winston and the NSTX technicians for their contributions to the implementation of the system and the TMB procedure.

\section{REFERENCES}

[1] J. Winter, et al., "Borontrimethyl $\mathrm{B}(\mathrm{CH} 3) 3$ - A less hazardous substance for boronization,” J. Nucl. Mater., 176\&177, pp 486-489, (1990).

[2] P. H. LaMarche, et al., "The diborane gas injection and exhaust system for the Tokamak Fusion Test Reactor," Fus. Technol., pp. 341-345, (1990).

[3] D. Mueller, et al., "Discharge cleaning on Tokamak Fusion Test Reactor after boronization," J. Vac Sci. Technol. A9(5), pp. 2713-2715, (Sep/Oct 1991).

[4] H. G. Esser, et al., "Boronization of COMPASS," J. Nucl. Mater., 186, pp 217-226, (1992).

[5] C. H. Skinner, et al., "Effect of Boronization on Ohmic Plasmas in NSTX," to be published in Nuclear Fusion.

[6] H. G. Esser, et al., "Plasma discharge fuelling by Trimethylboron - A new wall conditioning technique", Nuc. Fus. 32 (2), pp. 278-281, (1992).

[7] C. Boucher, et al., "Comparison of the three boronization techniques in TdeV”, J. Nucl. Mater., 196-198, pp 587-591, (1992).

[8] H. W. Kugel, et. al., "NSTX Glow Discharge Boronization and Plasma Fueling Boronization”, Bull. Am. Phys. Soc., 46 (8), pp. 262, (2001).

[9] C. Neumeyer, "National Spherical Torus Experiment (NSTX) Construction, Commissioning and Initial Operation:, Proceedings of $18^{\text {th }}$ IEEE/NPSS Symposium on Fusion Engineering, pp 63-66, (1999). 


\section{External Distribution}

Plasma Research Laboratory, Australian National University, Australia

Professor I.R. J ones, Flinders University, Australia

Professor J oão Canalle, Instituto de Fisica DEQ/IF - UERJ , Brazil

Mr. Gerson O. Ludwig, Instituto Nacional de Pesquisas, Brazil

Dr. P.H. Sakanaka, Instituto Fisica, Brazil

The Librarian, Culham Laboratory, England

Library, R61, Rutherford Appleton Laboratory, England

Mrs. S.A. Hutchinson, JET Library, England

Professor M.N. Bussac, Ecole Polytechnique, France

Librarian, Max-Planck-Institut für Plasmaphysik, Germany

J olan Moldvai, Reports Library, MTA KFKI-ATKI, Hungary

Dr. P. Kaw, Institute for Plasma Research, India

Ms. P.J . Pathak, Librarian, Insitute for Plasma Research, India

Ms. Clelia De Palo, Associazione EURATOM-ENEA, I taly

Dr. G. Grosso, Instituto di Fisica del Plasma, Italy

Librarian, Naka Fusion Research Establishment, J AERI, J apan

Library, Plasma Physics Laboratory, Kyoto University, J apan

Research Information Center, National Institute for Fusion Science, J apan

Dr. O. Mitarai, Kyushu Tokai University, J apan

Library, Academia Sinica, Institute of Plasma Physics, People's Republic of China

Shih-Tung Tsai, Institute of Physics, Chinese Academy of Sciences, People's Republic of China

Dr. S. Mirnov, TRINITI, Troitsk, Russian Federation, Russia

Dr. V.S. Strelkov, Kurchatov Institute, Russian Federation, Russia

Professor Peter Lukac, Katedra Fyziky Plazmy MFF UK, Mlynska dolina F-2, Komenskeho Univerzita, SK-842 15 Bratislava, Slovakia

Dr. G.S. Lee, Korea Basic Science Institute, South Korea

Mr. Dennis Bruggink, Fusion Library, University of Wisconsin, USA

Institute for Plasma Research, University of Maryland, USA

Librarian, Fusion Energy Division, Oak Ridge National Laboratory, USA

Librarian, Institute of Fusion Studies, University of Texas, USA

Librarian, Magnetic Fusion Program, Lawrence Livermore National Laboratory, USA

Library, General Atomics, USA

Plasma Physics Group, Fusion Energy Research Program, University of California at San Diego, USA

Plasma Physics Library, Columbia University, USA

Alkesh Punjabi, Center for Fusion Research and Training, Hampton University, USA

Dr. W.M. Stacey, Fusion Research Center, Georgia Institute of Technology, USA

Dr. J ohn Willis, U.S. Department of Energy, Office of Fusion Energy Sciences, USA

Mr. Paul H. Wright, Indianapolis, Indiana, USA 
The Princeton Plasma Physics Laboratory is operated by Princeton University under contract with the U.S. Department of Energy.

\author{
Information Services \\ Princeton Plasma Physics Laboratory \\ P.O. Box 451 \\ Princeton, NJ 08543
}

Phone: 609-243-2750

Fax: 609-243-2751

e-mail: pppl_info@pppl.gov

Internet Address: http://www.pppl.gov 